\title{
Reduction of Defoliation in Citrus Caused by Mycosphaerella citri with a Novel Biocompatible Fungicide
}

\author{
R. J. McGovern, University of Florida-IFAS, Plant Pathology Department, Gainesville 32611; A. E. Winston, \\ Church \& Dwight Co., Inc., Princeton, NJ 08540; R. E. Rouse, University of Florida-IFAS, Southwest Florida Re- \\ search and Education Center, Immokalee, FL 34142; and A. W. Welch, Jr., Welch Agricultural Services, Bradenton, \\ FL 34206
}

\begin{abstract}
McGovern, R. J., Winston, A. E., Rouse, R. E., and Welch, A. W., Jr. 2003. Reduction of defoliation in citrus caused by Mycosphaerella citri with a novel biocompatible fungicide. Plant Dis. 87:134-138.

A novel, biocompatible fungicide, CD-2346, was evaluated for management of defoliation associated with greasy spot (Mycosphaerella citri Whiteside) in orange (Citrus sinensis (L.) Osbeck) and grapefruit (Citrus $\times$ paradisi Macfad.). This product contains potassium bicarbonate, potassium carbonate, urea, and a surfactant. CD-2346 (7.0 kg/ha) and a half-rate combination of CD-2346 + benomyl $(0.55 \mathrm{~kg} / \mathrm{ha})$ were compared with a higher rate of benomyl $(1.1$ $\mathrm{kg} / \mathrm{ha}$ ) and commercial standards of oil (petroleum distillate FC-435-66 [70 to 93.5 liters/ha]) or oil (46.8 liters/ha) + copper sulfate (2.2 to $2.8 \mathrm{~kg} / \mathrm{ha})$. Fungicide efficacy was assessed using the area under the defoliation progress curve (AUDPC) and final defoliation in entire trees or final greasy spot severity in individual leaves. All fungicide treatments reduced the AUDPC, and all but benomyl reduced either final defoliation percentage or disease severity in individual leaves. CD-2346 and the reduced-rate combination of CD-2346 + benomyl were generally equal or superior to the full rate of benomyl in decreasing the AUDPC; CD-2346 + benomyl was equivalent to oil in reducing the AUDPC. Oil and CD-2346 treatments similarly reduced final defoliation, but oil + copper sulfate was superior to CD-2346 in reducing the AUDPC and final greasy spot defoliation or severity.
\end{abstract}

Additional keywords: Armicarb SF, fungal diseases, in vitro inhibition, sustainable agriculture, tropical climate

Greasy spot, caused by Mycosphaerella citri Whiteside, was first reported in Florida in 1915 (10) and remains one of the most economically significant foliar diseases of citrus in the state. The disease also occurs in the Caribbean and in areas in Central and South America and Asia with similar warm, humid climates (32). Leaves of all commercially grown Citrus spp. and many related genera are susceptible to some extent (34).

Disease symptoms progress from yellow spots on the adaxial leaf surface to irregu-

Corresponding author: R. J. McGovern

E-mail: rjm@mail.ifas.ufl.edu

This research was supported by the Florida Agricultural Experiment Station, and approved for publication as Journal Series No. R-07605.

The use of trade names in this publication is solely for the purpose of providing specific information. The authors and the University of Florida-IFAS do not guarantee or warranty the products named, and references to them in this publication does not signify our approval to the exclusion of other products of suitable composition.

Accepted for publication 3 September 2002.

Publication no. D-2002-1120-03R

(C) 2003 The American Phytopathological Society lar greasy-appearing lesions on both sides of leaves, and premature defoliation. Although initial infection of citrus leaves by $M$. citri generally occurs in July and August in Florida, after the onset of the rainy season, greasy spot has a long incubation period, usually exceeding 4 months on orange (Citrus sinensis (L.) Osbeck) and grapefruit (Citrus $\times$ paradisi Macfad.) (35). Greasy spot defoliation in central and south Florida may occur before full leaf symptoms develop but generally is not extensive until after the onset of cold weather in December. In Florida, losses of up to 25 and $45 \%$ of fruit yield of sweet orange and grapefruit, respectively, have been caused by defoliation induced by $M$. citri (32). Fruit losses in 'Valencia' orange of up to $23 \%$ attributed to defoliation from greasy spot were reported in Cuba (8). Severe defoliation also may make infected trees less able to recover from cold damage (37).

Under low inoculum densities, greasy spot management usually is achieved with a single application of an emulsified petroleum oil distillate (FC-435-66 or FC-45566) made from June through early August in orange produced for processing (29). An application of oil plus a copper fungicide in June or July, followed by a second spray in late August or early September, gener- ally is required to control the disease in highly susceptible citrus such as grapefruit harvested for the fresh market, or in groves with high inoculum densities (minimally managed or older groves; 29). Although this combination is effective, copper has been shown to inhibit growth of citrus as a result of accumulation to toxic levels in acidic soils, and reduction of colonization of citrus roots by the beneficial mycorrhizal fungus Glomus intraradices $(1,2,11)$.

There is increased interest in the identification of reduced-risk and sustainable alternatives to currently used fungicides because of food safety and environmental protection issues. One such biocompatible approach includes the use of carbonate and bicarbonate salts of ammonium and sodium for the management of pathogens in a wide variety crops $(15,23,24,28)$. Sporadic research conducted over the last 70 years also has examined the potential of these compounds to suppress postharvest rots in citrus caused by Penicillium spp. $(3,4,12,13,31)$. Sodium bicarbonate was routinely used for commercial disinfestation of citrus against Penicillium spp. in California during the late 1920s and postharvest use of sodium carbonate is increasing in the state $(17,31)$.

Suppression of plant pathogens during crop production and after harvest by two other biocompatible chemicals, potassium carbonate and potassium bicarbonate, also has been documented. Potassium bicarbonate reduced a number of foliar or fruit diseases in ornamentals and vegetables (9,18-20,22,25,39), and postharvest diseases of lemon ( $C$. limon), orange, bell pepper (Capsicum annuum), and potato (Solanum tuberosum) $(9,24,31)$. Potassium carbonate reduced post harvest diseases of carrot (Daucus carota), citrus, and potato $(24,28,31)$.

Benomyl, a benzimidazole fungicide, was used in the past for greasy spot control, but is no longer recommended because of the development of resistance to this fungicide by $M$. citri in central Florida the 1970s (36). No additional data is available on the prevalence of resistance of $M$. citri to benomyl in the state. However, significant reduction of greasy spot severity and defoliation by benomyl was reported in research conducted in 1991 and 1992 in central Florida, suggesting that resistance to benomyl in the fungus was 
not uniformly prevalent (33). In addition, the rapid development of a new area for citrus production, southwest Florida, in the early 1990 s generated interest in the revaluation of benomyl for greasy spot control and resistance management strategies for the fungicide.

The primary objective of our research was to evaluate the effectiveness of a novel, biocompatible fungicide alone and in combination with benomyl in managing defoliation in orange and grapefruit caused by $M$. citri. A secondary objective of this study was to conduct preliminary investigations of possible mechanisms underlying the activity of the fungicide.

\section{MATERIALS AND METHODS}

In vitro evaluation. We tested the ability of CD-2346 (Church \& Dwight Co., Inc., Princeton, NJ) and its constituents to inhibit the growth of $M$. citri in two in vitro experiments using two isolates of the fungus from west-central and southwest Florida. This fungicide consists of a proprietary formulation containing potassium bicarbonate, potassium carbonate, urea, and a surfactant. (A label for this biocompatible fungicide under the trade name of Armicarb SF is currently pending before the USEPA.)

One-quarter strength acidified potato dextrose agar (1/4APDA) amended with CD-2346, potassium carbonate, potassium bicarbonate, or urea at $0.5 \% \mathrm{wt} / \mathrm{vol}$ was used for inhibition assays. This same rate was used to test CD-2346 in the field and was selected to compare the relative inhibitory abilities of the individual components of the fungicide because their percent contribution to CD-2346 is unknown. (The surfactant used in CD-2346 was not available for testing). The $\mathrm{pH}$ of each amended medium was compared with nonamended $1 / 4 \mathrm{APDA}$ at $40^{\circ} \mathrm{C}$ shortly before the medium solidified to determine whether a $\mathrm{pH}$ effect may be involved in inhibition of $M$. citri.

Growth inhibition assays were conducted using five sterile toothpick tips that were inserted into an actively growing culture of $M$. citri and then placed in equidistant positions in the test agar. One petri dish served as a replication, with three replications per medium amendment; dishes were arranged using a randomized complete block design in an incubator set at $24^{\circ} \mathrm{C}$. After 10 days, the diameter of the fungal colony arising from each toothpick in the amended medium was measured and compared with the diameter of $M$. citri colonies on nonamended 1/4APDA. The experiment was repeated twice for each isolate.

We hypothesized that the activity of CD2346 may be due, in part, to the alkaline hydrolysis of urea leading to the production of ammonia and ammonium-containing products. Therefore, we tested for the presence of ammonia in a $0.5 \% \mathrm{wt} / \mathrm{vol}$ solution of CD-2346 in sterile deionized water using sterile capped bottles. Controls were provided by sterile water and urea $(0.5 \% \mathrm{wt} / \mathrm{vol})$. The assay was conducted three times at 24 to $27^{\circ} \mathrm{C}$ using a commercial ammonia detection kit (Aqua Lab V, Marvel, Inc., Glendale Heights, IL) at 0.5-, $1.0-$, and 2.0-h intervals.

Field sites. Four field experiments were conducted during 1994 through 1997 to test the effectiveness of CD-2346 in managing greasy spot defoliation. In the 199495 season, experimental sites were chosen within two commercial groves in Felda and Immokalee, southwest Florida, consisting of 6-year-old 'Hamlin' and 4-year-old 'Valencia' orange trees, respectively. A 6year-old mixed planting of grapefruit trees, including 'Flame', 'Marsh', 'Ray Ruby', 'Rio Red', and 'Ruby Red', located at the Southwest Florida Research and Education Center in Immokalee, was used in the 1995-96 season. A 20-year-old grove of 'Valencia' orange located in Bradenton, west-central Florida, was selected for research in the 1996-97 season. The former two sites had previously experienced low to moderate inoculum densities of $M$. citri, while the latter two sites had a history of moderate to high inoculum densities.

Hamlin and Valencia oranges, 199495. In the Hamlin grove, CD-2346 (7.0 $\mathrm{kg} / \mathrm{ha}$ ) and a combination of a half-rate of this fungicide plus a reduced rate of benomyl (Benlate 50 DF, 0.55 kg/ha; E. I. Dupont de Nemours \& Co., Inc., Wilmington, $\mathrm{DE})$ were compared with a higher rate of benomyl $(1.1 \mathrm{~kg} / \mathrm{ha})$ and the commercial standard, oil (Sunspray 7E, 70 liters/ha; Sunoco, Inc. Philadelphia, PA). The rate of CD-2346 was selected based on screening for phytotoxicity in citrus and other crops (R. J. McGovern, unpublished data). The same fungicide treatments and rates were tested in the Valencia grove, but the rate of oil was increased to 93.5 liters/ha. The reduced-rate combination of CD-2346 and benomyl was tested for the possibility of increased effectiveness and cost-saving benefits. Fungicide treatments and a nontreated control were replicated six times using 10-tree blocks arranged in a randomized complete block design. Fungicides were applied once by means of a commercial airblast sprayer on 6 and 20 July 1994 in the Hamlin and Valencia groves, respectively. Defoliation percentages were estimated by viewing the canopy of each tree from both sides of the row monthly in mid- to late November 1994 through February 1995 using a modified Horsfall-Barratt disease rating scale where $1=0 \%$ defoliation and $12=100 \%$ defoliation (14). We found that this defoliation assessment technique correlated well $\left(r^{2}=\right.$ 0.97 ) with the measurement of greasy spot severity on individual leaves of Valencia orange (21). Similarly, analysis of data from other research (38) revealed a strong negative correlation $\left(r^{2}=-0.81\right)$ between greasy spot severity on individual leaves and canopy density in Ruby Red grapefruit.

In vitro inhibition studies, ammonia detection, final defoliation percentage, and area under the defoliation progress curve (AUDPC) were analyzed by analysis of variance (SAS Institute, Cary, NC). Means were separated using Fisher's protected least significant difference (LSD) test $(P \leq$ 0.05). Percentage data were transformed prior to analysis by arc sine square root transformation where appropriate. Correlation analysis (SAS Institute) also was performed on in vitro data to look for possible correlations between the $\mathrm{pH}$ and solubility of CD-2346 components and inhibition of M. citri.

Grapefruit, 1995-96. Fungicides evaluated included CD-2346 (7.0 kg/ha), benomyl $(1.1 \mathrm{~kg} / \mathrm{ha})$, the reduced-rate combination of CD-2346 $(3.5 \mathrm{~kg} / \mathrm{ha})$ and benomyl $(0.55 \mathrm{~kg} / \mathrm{ha})$, and oil (46.8 liters/ha) + copper hydroxide (Kocide 101, $2.2 \mathrm{~kg} / \mathrm{ha}$; Griffin L.L.C., Valdosta, GA). Fungicide treatments and a nontreated control were replicated five times using a five-tree block of each of the five grapefruit cultivars arranged in a randomized complete block design. Fungicides were applied with a commercial airblast sprayer on 5 July and 8 September 1995. Defoliation data were obtained and analyzed monthly from November 1995 through February 1996 as described above.

Valencia orange, 1996-97. Fungicide treatments and rates were the same as those evaluated on grapefruit in the previous experiment, with the exception of copper sulfate, which was increased to $2.8 \mathrm{~kg} / \mathrm{ha}$. Fungicide treatments and a nontreated control were replicated five times using 10-tree blocks arranged in a randomized complete block design. Fungicides were applied with a commercial airblast sprayer on 27 June and 27 August 1996. The monthly progress of greasy spot defoliation was not recorded in this experiment. However, in mid-February 1997, final greasy spot severity (percentage of leaf surface diseased) was estimated on the remaining leaves (average $=10$ ) on one randomly selected shoot from each of the 10 trees per replication using the same rating scale as above.

\section{RESULTS}

In vitro experiments. The inhibitory effects of the tested materials did not differ significantly (Fisher's protected LSD test, $P \leq 0.05)$ within $M$. citri isolate between experiments but did differ between isolates. Therefore, the data for both experiments were combined and treatment effects were analyzed separately for each isolate. All materials tested except urea significantly reduced the growth of $M$. citri, with CD-2346 being the most effective (Table 1). The $\mathrm{pH}$ of the test media 
ranged from 4.0 (nonamended $1 / 4 \mathrm{APDA}$ ) to $9.5\left(1 / 4 \mathrm{APDA}+\mathrm{K}_{2} \mathrm{CO}_{3}\right)$. When the results from the two $M$. citri isolates were analyzed, very low correlations were observed between media $\mathrm{pH}$ and growth inhibition; the $r^{2}$ values were -0.43 and -0.47 for the isolates from west-central and southwest Florida, respectively. Ammonia was consistently detected at approximately $3 \mathrm{ppm}$ from 0.5 to $2.0 \mathrm{~h}$ after dissolving CD-2346 in sterile water (Table 2). Ammonia was not detected in either sterile water alone or in a solution of urea in sterile water. The solubilities of $\mathrm{NH}_{2} \mathrm{CONH}_{2}, \quad \mathrm{KHCO}_{3}$, $\mathrm{K}_{2} \mathrm{CO}_{3}$, and CD-2346 in $1 / 4 \mathrm{APDA}$ are not known, but the solubilities by weight of the first three chemicals in water at $20^{\circ} \mathrm{C}$ are $100,22.0$, and $52.8 \%$, respectively (5). Only weak correlations were obtained when solubility in water was compared to growth inhibition of the two $M$. citri isolates by the three chemicals; the $r^{2}$ values were 0.43 and 0.44 for the isolates from west-central and southwest Florida, respectively.

Field experiments. None of the treatments produced detectable phytotoxicity (dieback, leaf distortion, or foliar necrosis). Negligible defoliation from infection by $M$. citri was observed in the orange and grapefruit groves until December in all four experiments. Defoliation was moderate in the Hamlin orange and younger planting of Valencia, and moderate to high in the grapefruit and older Valencia grove. No significant differences (Fisher's protected LSD test, $P \leq 0.05$ ) in greasy spot defoliation were observed among the five

Table 1. The effect of urea, potassium bicarbonate, potassium carbonate, and an experimental fungicide, CD-2346, on in vitro growth of two isolates of Mycosphaerella citri

\begin{tabular}{lccc}
\hline & & \multicolumn{2}{c}{ Colony diameter $(\mathbf{m m})^{\mathbf{x}}$} \\
\cline { 3 - 4 } Treatment $^{\mathbf{y}}$ & $\mathbf{p H}$ at $\mathbf{4 0}^{\circ} \mathbf{C}^{\mathbf{z}}$ & M. citri-wc & M. citri-sw \\
\hline $1 / 4 \mathrm{APDA}$ & 4.0 & $10.4 \mathrm{a}$ & $10.6 \mathrm{a}$ \\
$\mathrm{NH}_{2} \mathrm{CONH}_{2}$ & 4.2 & $10.8 \mathrm{a}$ & $10.4 \mathrm{a}$ \\
$\mathrm{KHCO}_{3}$ & 7.7 & $9.1 \mathrm{~b}$ & $8.7 \mathrm{~b}$ \\
$\mathrm{~K}_{2} \mathrm{CO}_{3}$ & 9.5 & $5.8 \mathrm{c}$ & $5.2 \mathrm{c}$ \\
$\mathrm{CD}_{2} 2346$ & 6.5 & $0.0 \mathrm{~d}$ & $0.0 \mathrm{~d}$ \\
\hline
\end{tabular}

${ }^{\mathrm{x}}$ Colony diameter of isolates of $M$. citri from west central (wc) and southwest (sw) Florida was measured after 10 days at $24^{\circ} \mathrm{C}$. Each isolate was tested twice and the data were pooled by isolate to analyze treatment effects. Means within columns followed by different letters are significantly different by Fisher's protected least significant difference $(P \leq 0.05)$.

y Treatments were incorporated into one-quarter acidified potato dextrose agar ( $1 / 4 \mathrm{APDA})$ at $0.5 \%$ $\mathrm{wt} / \mathrm{vol}$. CD-2346 is a proprietary formulation of $\mathrm{NH}_{2} \mathrm{CONH}_{2}, \mathrm{~K}_{2} \mathrm{CO}_{3}, \mathrm{KHCO}_{3}$, and a surfactant.

${ }^{\mathrm{z}}$ The $\mathrm{pH}$ of $1 / 4 \mathrm{APDA}$ alone and $1 / 4 \mathrm{APDA}$ amended with $\mathrm{NH}_{2} \mathrm{CONH}_{2}, \mathrm{~K}_{2} \mathrm{CO}_{3}, \mathrm{KHCO}_{3}$, or CD-2346 was tested twice before the media solidified.

Table 2. Detection of ammonia production from sterile $\mathrm{H}_{2} \mathrm{O}$, urea and CD-2346

\begin{tabular}{|c|c|c|c|}
\hline \multirow[b]{2}{*}{ Treatment $^{\mathrm{z}}$} & \multicolumn{3}{|c|}{ Ammonia $(\mathbf{p p m})^{\mathrm{y}}$} \\
\hline & $0.5 \mathrm{~h}$ & $1.0 \mathrm{~h}$ & $2.0 \mathrm{~h}$ \\
\hline Sterile deionized $\mathrm{H}_{2} \mathrm{O}$ & $0.0 \mathrm{a}$ & $0.0 \mathrm{a}$ & $0.0 \mathrm{a}$ \\
\hline $\mathrm{NH}_{2} \mathrm{CONH}_{2}, 0.5 \% \mathrm{wt} / \mathrm{vol}$ & $0.0 \mathrm{a}$ & $0.0 \mathrm{a}$ & $0.0 \mathrm{a}$ \\
\hline CD-2346, $0.5 \% \mathrm{wt} / \mathrm{vol}$ & $3.0 \mathrm{~b}$ & $3.0 \mathrm{~b}$ & $3.0 \mathrm{~b}$ \\
\hline
\end{tabular}

${ }^{\mathrm{y}}$ The assay was conducted three times at 24 to $27^{\circ} \mathrm{C}$ in sterile capped plastic bottles using a commercial ammonia detection kit (Aqua Lab V, Marvel, Inc.).

${ }^{\mathrm{z}}$ Sterile deionized water was used to prepare the treatment dilutions. CD-2346 is a proprietary formulation of $\mathrm{NH}_{2} \mathrm{CONH}_{2}, \mathrm{~K}_{2} \mathrm{CO}_{3}, \mathrm{KHCO}_{3}$, and a surfactant. Means within columns followed by different letters are significantly different by Fisher's protected least significant difference $(P \leq$ 0.05). Means represent pooled data from three experiments. grapefruit cultivars used, and these data were pooled to test treatment effects.

All fungicides and fungicide combinations significantly reduced the AUDPC in orange and grapefruit (Table 3). CD-2346 and the reduced-rate combination of this fungicide plus benomyl were equal or superior to the full rate of benomyl in reducing the AUDPC. In addition, CD-2346 and CD-2346 + benomyl were equivalent to oil in reducing the AUDPC in one of two, and both experiments, respectively, in which these treatments were compared. A benefit from combining reduced rates of CD-2346 and benomyl was not consistently observed in this study.

With the exception of benomyl, all individual fungicides and fungicide combinations significantly reduced final tree defoliation percentage or greasy spot severity in individual shoots (Table 4). Oil and CD2346 were similar in their effect on final defoliation in the two experiments in which they were compared. However, oil + copper was superior to CD-2346 and CD2346 + benomyl in reducing the AUDPC and final defoliation in grapefruit in 1996, and in lowering greasy spot severity in the older Valencia grove in 1997 (Tables 3 and 4).

\section{DISCUSSION}

The results of our in vitro experiments indicate that CD-2346 and all of its components except urea are directly inhibitory to $M$. citri. In other research, higher concentrations of potassium carbonate and potassium bicarbonate were found to be fungistatic in vitro to Helminthosporium solani, while a lower rate of potassium carbonate than used in our research inhibited mycelial growth of Rhizoctonia carotae, Botrytis cinerea, and Sclerotinia sclerotiorum (24,28). Other researchers demonstrated that a higher concentration of urea than used in our research was fungitoxic to Septoria nodorum in vitro, and protected wheat from infection by the pathogen when applied as a foliar spray (27). These researchers theorized that the suppressive effect of urea in the field may be due to its breakdown into ammonia,

Table 3. Effect of fungicides on the area under the defoliation progress curve (AUDPC) for greasy spot epidemics on orange and grapefruit in southwest Florida, 1994-1996

\begin{tabular}{|c|c|c|c|}
\hline \multirow[b]{2}{*}{ Treatment $^{x}$} & \multicolumn{3}{|c|}{ AUDPCw $^{w}$} \\
\hline & Hamlin orange, 1994-95 & Valencia orange, 1994-95 & Grapefruit, 1995-96 \\
\hline Nontreated control & $2,350.2 \mathrm{a}$ & $2,470.6 \mathrm{a}$ & $2,925.5 \mathrm{a}$ \\
\hline CD-2346 (7 kg/ha) & $1,810.7 \mathrm{~b}$ & $1,713.4 \mathrm{c}$ & $1,636.0 \mathrm{~b}$ \\
\hline Benomyl (1.1 kg/ha) & $1,903.2 \mathrm{~b}$ & $2,134.2 \mathrm{~b}$ & $2,015.8 \mathrm{~b}$ \\
\hline CD-2346 $(3.5 \mathrm{~kg} / \mathrm{ha})+$ benomyl $(0.55 \mathrm{~kg} / \mathrm{ha})$ & $1,598.6 \mathrm{~b}$ & $1,619.6 \mathrm{~cd}$ & $1,981.1 \mathrm{~b}$ \\
\hline Oil $(70-93.5 \text { liters } / \mathrm{ha})^{\mathrm{z}}$ & $1,628.0 \mathrm{~b}$ & $1,410.1 \mathrm{~d}$ & NT \\
\hline Oil (46.8 liters/ha)+ copper sulfate $(2.2 \mathrm{~kg} / \mathrm{ha})$ & NT & NT & $952.0 \mathrm{c}$ \\
\hline
\end{tabular}

${ }^{w}$ AUDPC was based on the measurement of percent tree defoliation over time. Defoliation was assessed monthly from mid- to late November, December, January, and February in blocks of 10 orange tree in 1994-95 and 5 grapefruit trees in 1995-96. Means within columns followed by different letters are significantly different by Fisher's protected least significant difference $(P \leq 0.05)$; NT $=$ not tested.

${ }^{x}$ CD-2346 is a proprietary formulation of potassium carbonate, potassium bicarbonate, urea, and surfactant.

y Trees were part of a planting consisting of grapefruit cvs. Flame, Marsh, Ray Ruby, Rio Red, and Ruby Red.

${ }^{\mathrm{z}}$ Oil at 70 and 93.5 liters/ha was used on the Hamlin and Valencia oranges, respectively. 
which has well-known fungitoxic properties.

CD-2346 exerted a significantly greater inhibitory effect than any of its constituents; therefore, this increased activity may result from the chemical reaction of its components. One possibility is that slow alkaline hydrolysis of urea results in the production over time of various ammonium-containing compounds that may be fungitoxic. A typical initial alkaline catalyzed aqueous hydrolysis reaction for urea can be written as $\left(\mathrm{NH}_{2}\right)_{2} \mathrm{CO}+\mathrm{H}_{2} \mathrm{O} \rightarrow$ $\mathrm{NH}_{2} \mathrm{CO}_{2} \mathrm{NH}_{4}$ (urea + water $\rightarrow$ ammonium carbamate).

Subsequent to the initial hydrolysis, various other ammonium- and nitrogencontaining compounds may be formed, including ammonium bicarbonate and mixed potassium ammonium carbonate, potassium carbamate, ammonium hydroxide, and ammonia, the latter of which was detected in our in vitro assays. In essence, the hydrolysis reaction involving urea allows active species to be present over a longer period of time than would be possible with independent application of each constituent or byproduct. This is an advantageous characteristic for suppression of slowly developing diseases such as greasy spot.

The direct effect of the surfactant contained in CD-2346 on M. citri could not be tested and, therefore, cannot be ruled out by this research. Other researchers have observed synergistic interactions between bicarbonates and various surfactants against plant pathogens in vivo that may be due to direct effects of the surfactants $(12,15,39)$.

Our data do not support $\mathrm{pH}$ alteration as a probable mechanism for in vitro inhibition of $M$. citri by CD-2346. Other researchers have attributed microbial inhibition by bicarbonates to the direct effect of the bicarbonate ion or to that mechanism in combination with $\mathrm{pH}$ effects and buffering capacity $(7,26)$. We believe that it also is unlikely that differences in the solubility of the components of CD-2346 could account for difference observed in their inhibition of $M$. citri.

The induction of host resistance by CD2346 or one or more of its constituents cannot be discounted. Another possible mechanism for the suppression of greasy spot by CD-2346 in the field may have been reduction of primary inoculum (ascospores) in leaf litter or in hastening the decomposition of the litter itself. Ascospore production in apple leaves infected by Venturia inaequalis was reduced by up to $89.2 \%$ by treatment with urea (6). It was theorized that ascospore inhibition may have resulted from enhancement of microbial antagonists, acceleration of leaf decomposition, or inhibition of pseudothecia by a nitrogen-carbon imbalance.

Our field experiments demonstrated that, under moderate inoculum levels such as those observed in young groves of Hamlin and Valencia orange, CD-2346 or CD-2346 + benomyl at reduced rates managed greasy spot defoliation as well as oil, the commercial standard. Reduction of the AUDPC by benomyl but not the final defoliation percentage suggests that both benomyl-sensitive and -insensitive strains of $M$. citri may have been present in the groves used. Benomyl initially may have reduced the number of highly sensitive or totally inhibited partially sensitive strains of the fungus, allowing insensitive strains to predominate by the conclusion of the experiments. This hypothesis may explain why the reduced-rate combination of CD2346 + benomyl was as effective as oil in AUDPC reduction but not as effective in final reduction of greasy spot defoliation in the Valencia grove in 1995.

Although significant decreases in defoliation were observed with CD-2346 in each experiment, it was not as effective under high greasy spot inoculum densities (in the grapefruit and older Valencia groves) as the current standard treatment of copper sulfate + oil. Increasing the number of applications per season may improve the performance of CD-2346 in the control of greasy spot. However, this approach may only be practical for small, intensively managed groves because of time limitations for completing fungicide application for greasy spot control in larger groves. Nevertheless, use of a biocompatible fungicide such as CD-2346 avoids reliance on petroleum-based products such as oil and the deleterious impact of copper accumulation in soil. The novel fungicide evaluated in this study may have potential for the control of other plant diseases and for fungicide resistance management when used in combination or rotation with other fungicides. Separate research has demonstrated that CD-2346 can suppress a number of other foliar pathogens $(19,20)$. Although production of benomyl was discontinued in 2001, fungicide resistance management in $M$. citri is vital because resistance to such likely benomyl replacements as strobilurin compounds has been reported in related fungi $(16,30)$.

\section{ACKNOWLEDGMENTS}

We thank B. Cauley, J. Kendall, F. Ligas, E. Ontermaa, M. Pachioli, T. Seijo, and J. Sherrod for technical assistance; and Silver Strand and A. Duda \& Sons, Inc. for use of their groves.

\section{LITERATURE CITED}

1. Alva, A. K. 1993. Copper contamination of sandy soils and effects on young Hamlin orange trees. Bull. Environ. Contam. Toxicol. 51:857-864.

2. Alva, A. K., Huang, B., Prakash, O., and Paramasivam, S. 1999. Effects of copper rates and soil $\mathrm{pH}$ on growth and nutrient uptake by citrus seedlings. J. Plant Nutr. 22:1687-1699.

3. Arimoto, Y., Homma, Y., and Misato, T. 1977. The effect of sodium hydrogencarbonate on the occurrence of citrus storage diseases. J Pestic. Sci. 2:163-167.

4. Barger, W. R. 1928. Sodium bicarbonate as a citrus fruit disinfectant. Calif. Citrogr. 13:164, 172-174.

5. Budavari, S. ed. 1989. The Merck Index, 11th ed. S. Merck \& Co., Inc. Rahway, NJ.

6. Carisse, O., Philion, P., Rolland, D., and Bernier, J. 2000. Effect of fall application of fungal antagonists on spring ascospore production of the apple scab pathogen, Venturia inaequalis. Phytopathology 90:31-37.

7. Curran, D. M., and Montville, T. J. 1989. Bicarbonate inhibition of Saccharomyces

Table 4. Effect of fungicides on final greasy spot defoliation or severity in orange and grapefruit in southwest and west-central Florida, 1995-1997t

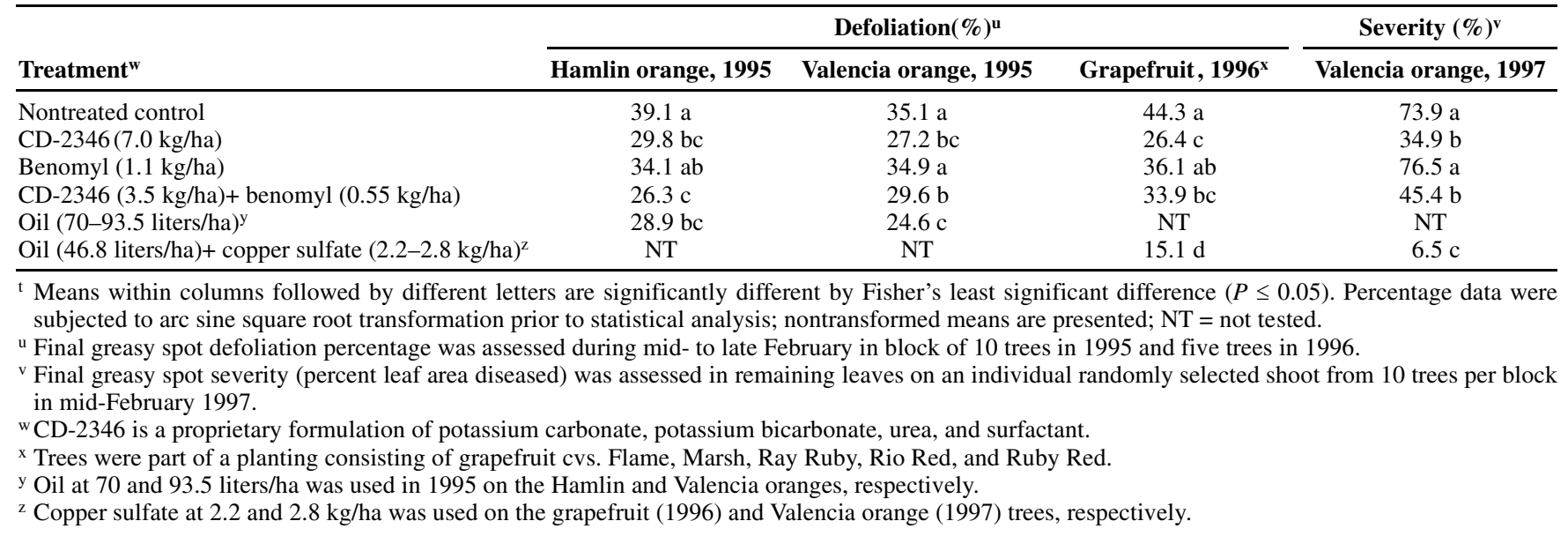


cerevisiae and Hansenula wingei growth in apple juice. Int. J. Food Microbiol. 8:1-9.

8. Diaz Alvarez, J. A. and Brown Manrique, O. 1985. Influencia de la mancha grasienta ( $M y$ cosphaerella citri Whiteside) sobre el rendimiento del naranjo Valencia. Cent. Agric. 12:127-137.

9. Fallik, E., Grinberg, S., and Ziv., O. 1997. Potassium bicarbonate reduces postharvest decay development on bell pepper fruits. J. Hortic. Sci. 72:35-41.

10. Fawcett, H. S. 1915. Citrus diseases of Florida and Cuba compared with those of California. Calif. Agric. Exp. Stn. Bull. 262.

11. Graham, J. H., Timmer, L. W., and Fardelmann, D. 1986. Toxicity of fungicidal copper in soil to citrus seedlings and vesicular-arbuscular mycorrhizal fungi. Phytopathology 76:66-70.

12. Homma, Y., Arimoto, Y., and Misato, T. 1981. Effect of emulsifiers and surfactants on the protective values of sodium bicarbonate. J. Pestic. Sci. 6:145-153.

13. Homma, Y., Arimato, Y., and Misato, T. 1981. The control of storage disease by sodium bicarbonate formulation. Proc. Int. Soc. Citricult. 2:823-825.

14. Horsfall, J. G., and Barratt, R. W. 1945. An improved grading system for measuring plant disease. (Abstr.) Phytopathology 35:655.

15. Horst, R. K., Kawamoto, S. O., and Porter, L. L. 1992. Effect of sodium bicarbonate and oils on the control of powdery mildew and black spot of roses. Plant Dis. 76:247-251.

16. Langston, D. 2002. Quadris resistance in gummy stem blight confirmed. Ga. Ext. Veg. News 2 (1):1-2.

17. Marloth, R. H. 1931. The influence of hydrogen-ion concentration and of sodium bicarbonate and related substances on Penicillium italicum and $P$. digitatum. Phytopathology 21:169-198.

18. McGovern, R. J. 1999. Evaluation of fungicides for control of Colletotrichum leaf spot in azalea. Fungic. Nematicide Tests 54:531.
19. McGovern, R. J., Davis, T. A., and Seijo, T. E. 2000. Evaluation of fungicides for foliar disease control in tomato. Fungic. Nematicide Tests 56:V108.

20. McGovern, R. J., and Harbaugh, B. K. 1999. Evaluation of fungicides for control of Botrytis blight and Cercospora leaf spot in lisianthus. Fungic. Nematicide Tests 54:544.

21. McGovern, R. J., and Sommerfeld, M. L. 1994. Evaluation of fungicides for control of greasy spot on orange. Fungic. Nematicide Tests. 49:378.

22. McGrath, M. T., and Shishkoff, N. 1999. Evaluation of biocompatible products for managing cucurbit powdery mildew. Crop Prot. 18:471-478.

23. Mlikota, F., and Smilanick, J. L. 1998. Control of Botrytis cinerea and postharvest gray mold on grapes with carbonate and bicarbonate salts. (Abstr.) Phytopathology 88:S64.

24. Olivier, C., Halseth, D. E., Mizbuti, E. S. G., and Loria, R. 1998. Postharvest application of organic and inorganic salts for suppression of silver scurf on potato tubers. Plant Dis. 82:213-217.

25. Palmer, C. L., Langhans, R. W., Horst. R. K., and Israel. H. W. 1996. Bicarbonates and Botrytis: V. Control of gray mold on greenhouse grown geraniums. (Abstr.) Phytopathology 85:1150.

26. Palmer, C. L., Horst, R. K., and Langhans, R. W. 1997. Use of bicarbonates to inhibit in vitro colony growth of Botrytis cinerea. Plant Dis. 81:1432-1438.

27. Peltonen, J., Kittila, S., Peltonen-Saino, P., and Karjalainen, R. 1991. Use of foliarapplied urea to inhibit development of Septoria nodorum in spring wheat. Crop Prot. 10:260-264.

28. Ricker, M. D., and Punja, Z. K. 1991. Influence of fungicide and chemical salt dip treatments on crater rot caused by Rhizoctonia carotae in long-term storage. Plant Dis. 75:470-474.
29. Roberts, P. D., and Timmer, L. W. 2001. 2001 Florida Citrus Pest Management Guide: Greasy Spot. Fact Sheet PP-144. University of Florida-IFAS, Gainesville.

30. Sierotzki, H., Parisi, S., Steinfeld, U., Tenzer, I., Poirey, S., and Gisi, U. 2000. Mode of resistance of respiration inhibitors at the cytochrome bcl enzyme complex of Mycosphaerella fijiensis field isolates. Pest Manage. Sci. 56:833-841.

31. Smilanick, J. L., Margosan, D. A., Mlikota, F., Usall, J., and Michael, I. F. 1998. Control of citrus green mold by carbonate and bicarbonate salts and the influence of commercial postharvest practices on their efficacy. Plant Dis. 83:139-145.

32. Timmer, L. W., and Graham, J. H. 2000. Greasy spot and similar diseases. Pages 25-29 in: Compendium of Citrus Diseases, 2nd ed. L. W. Timmer, S. M. Garnsey, and J. H. Graham, eds. American Phytopathological Society Press, St. Paul, MN.

33. Timmer, L. W., and Zitco, S. E. 1995. Evaluation of nutritional products and fungicides for control of greasy spot. Proc. Fla State Hortic. Soc. 108:83-87.

34. Whiteside, J. O. 1972. Histopathology of citrus greasy spot and identification of the causal fungus. Phytopathology 62:260-263.

35. Whiteside, J. O. 1976. Epidemiology and control of greasy spot, melanose, and scab in Florida citrus groves. PANS 22:243-249.

36. Whiteside, J. O. 1980. Tolerance of Mycosphaerella citri to benomyl in Florida citrus groves. Plant Dis. 64:300-302.

37. Whiteside, J. O. 1984. Spray programs. Citrus Ind. 65:23-27.

38. Zitko, S. E., and Timmer, L. W. 1998. Evaluation of fungicides for control of greasy spot on Ruby Red grapefruit. Fungic. Nematicide Tests 53:491.

39. Ziv, O., and Hagiladi, A. 1993. Controlling powdery mildew in euonymus with polymer coatings and bicarbonate solutions. HortScience 28:124-126. 